\title{
Religion and ecological justice in Africa: Engaging 'value for community' as praxis for ecological and socio-economic justice
}

Author:
Obaji M. Agbiji'
Affiliation:
'Research Institute for
Theology and Religion,
University of South Africa,
South Africa
Note:
This article is published in th
section Practical Theology
of the Society for Practical
Theology in South Africa.
Correspondence to:
Obaji Agbiji
Email:
obajiagbiji@gmail.com
Postal address:
PO Box 329 University of
South Africa 0003,
South Africa
Dates:
Received: 18 Mar. 2014
Accepted: 07 June 2014
Published: 30 Apr. 2015
How to cite this article:
Agbiji, O., 2015, 'Religion
and ecological justice in
Africa: Engaging "value
for community" as
praxis for ecological and
socio-economic justice',
HTS Teologiese Studies/
Theological Studies $71(2)$,
Art. \#2663, 10 pages.
http://dx.doi.org/10.4102/
hts.v71i2.2663
Copyright:
C 2015. The Authors.
Licensee: AOSIS
OpenJournals. This work is
licensed under the Creative
License.

License.
Read online:
This article embarked on a critical evaluation of religious leadership and ecological consciousness in Africa, using the case of the Nigerian Christian religious community. The article argued that the concept of ecological justice lacks strong theological conceptualisation in the Nigerian ecclesiastical community. Therefore, Ime Okopido's argument in favour of stewardship for the involvement of religious leadership in the pursuit of ecological and socioeconomic justice served as the starting point for this engagement. However, such engagement of the religious leadership and of the faithful should include developing ecological theological concepts, such as value for community, which are relevant to the context and resonate with indigenous cultures. Embarking on ecological activism, a change of lifestyles and finding other concrete ways of protecting the environment and biodiversity could ameliorate the crisis of ecological and socio-economic injustice in Africa by promoting, in particular, the praxis of value for community.

\section{Introduction}

The prevalent and endemic challenge of economic injustice in Africa has given rise to the scourge of poverty on the continent. Poverty in turn gives impetus to ecological injustice amongst African societies (Adeyemo 2001:31-35; Amoa 2001:152). As a result, faith communities in subSaharan Africa are gradually developing awareness of the dangers of ecological injustice and its connection with socio-economic injustice (Gosling [1986] 2010:323). However, not much has been achieved with regard to developing a strong Christian ecological ideological orientation and activism amongst the Nigerian ecclesial community in particular; such an orientation might stem the devastating impact of human beings on the environment.

So far, Ime Okopido's (2010) presentation to the Christian Association of Nigeria (CAN) effectively marked the beginning of the most significant attempt by the Christian religious community (in terms of a theological and an ideological orientation) to address ecological challenges. At a seminar in 2010 organised by CAN in Abuja, entitled 'The church in mission as an agent of transformation', Okopido (2010) presented a paper on the theme 'Church and environment'. In that paper, Okopido viewed religious leaders and the Christian community as 'stewards of God' and urged them to rise to the challenge of the environmental crisis and its negative impact on the living conditions of Nigerians. Underlying Okopido's paper is the assumption that ecological injustice has a direct link with socio-economic injustice in particular, which results in poverty and a negative impact on the environment (Nürnberger 1999:73; Tucker 2008:116-117). Therefore, Okopido's presentation, in which he used the concept of stewardship as a theological resource to motivate the church in her engagement in environmental activism, could be said to constitute an entry point for faith communities' endeavours with regard to ecological and economic justice. Very significantly, the need for a credible ecumenical theology (Gosling [1986] 2010) with regard to ecological and economic justice that is culturally relevant to African communities remains. Developing such a theology has become necessary, as this could promote a purposeful ideological orientation for sustainable ecological and economic justice praxis. In this article, my argument will be drawn from the perspectives of religion, theology and the anthropology of religion and the environment.

Whereas the concept of religion has never been without controversy (Woodhead 2011:121) the definition of religion is generally agreed on and involves beliefs, practices, and rituals related to the sacred (Koenig 2009:284). Religion is not just a typical function or variable amongst others, but is rather the root from which the different branches of life sprout and grow and by which they are continually nurtured (Koenig 2009:284). Accordingly, the increasing realisation of the importance of religion in all facets of life, both in developed and developing societies (Proctor 2006:165-166), 
is also resulting in a burgeoning literature on the importance of religion in addressing global challenges such as poverty and the environmental crisis. In Africa in particular, the role of religion in the quest to ameliorate the crises of poverty and environmental degradation cannot be overemphasised. This is especially because religion in a very crucial way pertains to the question of existence and the nexus between religion and existence is inseparable (Mbiti 1999:15). Religion has rules about conduct that guide life within a social group and is often organised and practiced within a community (Agbiji 2013:1). In this regard, the rules about conduct relate to the ethical provisions that religion provides to society and which help to sustain the social group or society. In effect, these ethical provisions are connected to socio-political, economic and environmental concerns of the community and can also be derived from the Christian faith.

As a theological discipline of the Christian faith, practical theology engages by 'focusing on global, local and particular issues with the intention of doing something about the reality and problems confronting society' (Hendriks 2010:284). In focusing on global and local issues such as poverty and ecological challenges, practical theology leads the process of change in a responsible way from both the perspectives of theology and the social sciences (Heitink 1999:113). In this case, practical theological environmental engagement concerns ecological injustice and how this affects issues of poverty and underdevelopment and vice versa - all of which have grave implications for Nigeria, South Africa, Africa and the world. Christian theological discourse that pertains to ecological injustice and its impact on economic injustice (and vice versa) could be engaged with from the perspective of Christian theological environmentalism.

With regard to Christian theological environmentalism (Christian stewardship, eco-justice and creation spirituality) (Hand \& Crowe 2012:3), this article draws on Christian stewardship, eco-justice, and creation spirituality. It relates to Christian stewardship as it seeks to engage with contemporary ecological discourses by looking at the concept of stewardship as relevant to the development of consciousness about both environmental and economic justice. However, the impact of this concept amongst African cultural societies is limited as it originates in the North American cultural context. With regard to eco-justice, the article seeks to engage Christian denominational and ecumenical institutions regarding the critical challenges of environmental degradation and the way these challenges impinge on economic and social justice. I will argue that human beings should view their uniqueness amongst other creatures as conferring on them a responsibility to maintain the created order as creatures in community with other creatures, where valuing other creatures and respecting their interdependence becomes inevitable. In the light of this stance, this article draws on creation spirituality. At the heart of the three approaches to ecological justice (Christian stewardship, eco-justice, and creation spirituality) is the quest for religion environmentalism.
Ecological justice is often rendered as eco-justice. The prefix 'eco' comes from the Greek word for 'house' (oikos) and is part of the etymological root of words like 'economy' and 'ecology', but also 'ecumenism' (World Council of Churches [WCC] 2011). With regard to justice, the environmental justice approach, 'eco-justice', challenges both humanity's destruction of the earth and the abuse of power which results in environmental damage, with poor people suffering the greatest impact (Conradie 2003:124; WCC 2011). With regard to the anthropology of religion and environment, religion is taken very seriously for its social and cultural impact, whatever its truth status may be. Moreover, religion is perceived as a part of human culture; it originates in the human spirit and as such is of great importance (Anderson 2012:11) for human existence and the created order. In this article, reference to religion is usually made in relation to the Christian faith.

Beginning with the introductory discussion, this article proceeds from the assumption that environmental and economic justice is crucial to African societies in the light of the enormous crisis of poverty on the continent. As such, a response is needed from ecclesiastical communities, in the sense of providing a relevant ecological and economic justice theological perspective that could assist in dealing with the crisis has become inevitable. Informed by this understanding, and in response to the decision of the Society of Practical Theology in South Africa to devote its 2014 conference to the crucial theme of 'Practical theology in Africa and human waste', with the sub-theme, 'Towards a theology of ecological justice as economic justice', I attempt in this article to make a contribution. The theme and sub-theme are both pertinent to and new to ecclesiastical circles in Nigeria. In order to make a meaningful contribution to the topical issue of the sub-theme, 'Towards a theology of ecological justice as economic justice', I will engage with Robert Osmer's (2008:4) four tasks of practical theology (the descriptive-empirical, interpretative, normative and pragmatic). In line with this view, the following will be considered:

- I will address the questions, 'What is going on?' and 'Why is it going on? (Osmer 2008:4) by seeking to develop a deeper (but modest) understanding of the global and contextual dynamics of the current crisis of ecological and economic injustice. I am conscious of the fact that these crises emanate from social dynamics in the wider society, and are outside the direct influence of the Christian ecclesiastical community, but I also take cognisance the absence of any practical-theological attempt to date to undertake an empirical study of the crisis, especially in Nigeria. In this regard, the development of a modest global and local understanding will be based on relevant literature on the topical issues of poverty and development, drawn from the social sciences, in addition to ecumenical documents, and sources relating to theology, religion and the anthropology of religion and environment.

- I will address the questions, 'What ought to be going on?' and 'How might the Christian church or faith community 
respond?' (Osmer 2008:4) specifically from the perspective of Christian ecumenical dialogue on the church and the environment (Okopido 2010), on the integrity of creation (WCC 1992:12) and on how the Christian church through her ministry can help to stem the crisis of ecological and economic injustice. Also, in addressing the questions, 'What ought to be going on?' and 'How might the faith community respond?', this article will lean on the concept of the integrity of creation as a middle axiom (Gosling [1986] 2010:322); WCC 1992:11-13) which enables the concerns of ecological and economic justice to be expressed from within a variety of cultural contexts other than those of the classical European and North American modes of thought (Gosling [1986] 2010:232). In addition, the 'what' and 'how' questions regarding the response of faith communities will draw inspiration from the anthropological understanding of religion as a collective representation of the community, as a social institution that serves to regulate management of the environment, and will stress the long-term consideration of religion as a vital source of the moral framework (Anderson 2012:9). I will first develop an understanding of the global and Nigerian scenario of the current ecological and economic crisis. This crisis has in part been attributed to human optimism engendered by religion and to how that optimism has endured, resulting in both human suffering and an ecological crisis of immense proportions.

\section{Nigerian ecological and economic injustice crisis: Towards a deeper understanding}

Extensive economic and technological activities have greatly enhanced global standards of living, especially in the developed world. Meanwhile, African countries including Nigeria have also benefitted from these global economic and technological advances. However, alongside these advances environmental challenges have also arisen, and these are of such magnitude that the very existence of planet Earth is threatened. Global climate change, acid rain, the depletion of the ozone layer, rapid rates of deforestation and significant increases in the rate of species lost suggest that the costs of global development are rising rapidly (Weaver, Rock \& Kusterer 1997:237).

Indeed, Nigeria and other parts of sub-Saharan Africa are currently experiencing the severe effects of environmental degradation arising from the extensive oil exploitation carried out by multinational companies such as Shell and Chevron. The Niger Delta area in particular is not only restive; vast farm lands can no longer be cultivated and aquatic life is wasting away because of oil spillages (Agbiji 2012:47). Apart from this, there are also imperialist activities which may be termed criminal and which are posing monumental environmental challenges to Nigeria. For example, five shiploads of toxic waste (3888 tons) originating from Italy were dumped at the small port of Koko in the Delta state, which is a predominantly Christian community (Ityavyar \&
Thomas 2013:2; Okopido 2010). Also, between 2000 and 2010 a Chinese company was discovered to have been dumping toxic waste into the upper reaches of the Cross River in the Ikom Local Government Area of Cross River State, under the pretext of wood production. Inadvertently, this has a direct negative impact on the environment and on aquatic life. Such negative impact includes health hazards, loss of species and employment opportunities. Besides the crises of ecological and economic injustice arising from the activities of multinational companies, there are also challenges arising from the Nigerian context; including population growth, poverty and poor governance.

Population growth, poverty and poor governance add to the pressure on natural resources and contribute to environmental decline in Nigeria. Soil erosion and a concomitant loss in terms of fertility, deforestation, water scarcity, water pollution, biodiversity, municipal and hazardous waste, and the impact of oil and gas development (Okopido 2010) are also increasingly felt in Nigeria. For example, if one takes the issue of poor governance and its negative impact on deforestation and species loss, the facts speak for themselves. As a result of poor governance, the supply of electric power in Nigeria is extremely poor: many rural communities are not supplied with electric power, neither are they able to afford cooking gas. In consequence, dwellers in these communities have no option but to cut down trees for fuel. Also, the prevailing poverty amongst many Nigerians contributes to the cutting down of timber in rural areas (for export for insignificant sums of money), which gives added impetus to deforestation.

In addition, hunters are often forced to hunt for game in order to be able to feed and care for their families. Unfortunately, their prey often includes species of animals that are facing extinction. In a typical rural environment in Nigeria, raising issues of animal rights, game reserves, forest reserves and endangered species not only sounds ridiculous; in fact, such issues hardly exist for ordinary people (Agbiji 2012:57-58). Worse still, desert encroachment, floods, poor crop yields and food shortages (which were not problems in the past) have suddenly become burning issues for local communities in Nigeria. Klaus Nürnberger (1999:73) has rightly observed that scarcity of food is caused by the over-exploitation of renewable resources. Whilst the human population continues to grow, the capacity of the land to produce food declines. This is partly due to pollution and erosion, and partly to the law of declining marginal productivity.

In response to the looming ecological crisis and the impending consequences thereof, the American economist, Jeffrey Sachs (2005:367), has warned that the on-going 'environmental degradation at local, regional and planetary scales threatens the long-term sustainability of all our social gains'. There is a danger that generations of Nigerians living in the Niger Delta area will be denied their sources of livelihood if the situation is not checked. There are also the deplorable health issues arising from gas flaring, water pollution and food poisoning caused by the on-going environmental pollution. 
Environmental challenges are in turn posing a monumental challenge to developmental efforts in Nigeria, especially in the field of agriculture, the sector in which most rural dwellers are employed. In order to guarantee the just and equitable co-existence of all life species on earth, both now and in the future, it is necessary to take relevant ethical considerations into account. This will include considering issues related to ecological and socio-economic justice. Religion could play a vital role in curbing these forms of injustice. But the question does arise as to how religion could also be a vital source for the reversal of the very crisis for which it is held to be responsible: the Christian faith that has been historically indicted for being at the root of on-going ecological and economic injustice.

\section{Religion, ecological and economic (in)justice}

Given claims that religion, and in this case the Christian faith, have contributed substantially to the on-going ecological and economic crisis, it will be pertinent to first explore in a modest way to what extent this indictment is justified. Thereafter, I will interrogate the practical responses of the Nigerian ecclesiastical community to the crisis. I will then engage with its theological orientation as a factor contributing to a sustainable praxis for ameliorating the crisis of ecological and economic injustice. This endeavour will assist with the first task, which is to understand 'what is going on and why is it going on?' (Osmer 2008:4), as explained in the introduction.

\section{Revisiting the religion and ecological crisis debate}

Foremost with regard to the indictment of religion, in particular the Christian faith, for being responsible for ecological and (to a considerable extent) economic injustice is the argument put forward by Lynn White Jr. White, in his 1967 thesis, argued that ' $[t]$ he historical roots of our ecologic crisis' lie in religious cosmology - specifically in Western Christianity's anthropocentrism and instrumentalist view of nature (White 1967 cited in Jenkins 2009:283). White's hypothesis is simple: 'What people do about their ecology depends on what they think of themselves in relation to the things around them' (1967, cited in Jenkins 2009:285). White's ideas (amongst other responses) set off an extended debate about the role of religion in creating and sustaining the West's increasingly successful control of the natural world through technology (Whitney 2005:1736) and economic activities. Whereas White's thesis has enormously contributed to the development of the debate around religion and ecology and the discipline, it has also attracted strenuous rebuttals from eco-theologians (Riley 2012:1). It should be noted however, that, although White's thesis has attracted many rejoinders, the debate has basically tended to accept his assumption about the cosmological roots of environmental problems and about the need to promote cultural change (1967, cited in Jenkins 2009:286). Because of limitations of space, it will suffice to consider a few responses to White's claims.
Contrary to White's view that Judeo-Christian beliefs and teachings bore 'a great burden of guilt' (White 1967, cited in Whitney 2005:1736) for the current environmental crisis, biblical scholars and eco-theologians such as James Barr, Carl Braaten, John Cobb, and Joseph Sittler argue that JudeoChristian tradition could more accurately be described as mandating a care-taking or stewardship relationship to the natural world (Whitney 2005:1736). As such, Christianity was not part of the problem, but rather part of the solution to environmental issues. From the purview of environmental ethicists, and of religion and ecology, there have been critical reflections on White's assumptions. Within environmental ethics, arguments from pragmatists, urbanists, and agrarians attempt to move the field away from focusing on anthropocentrism and nature's value in an attempt to shift discussion toward the political possibilities of civic experience (Jenkins 2009:284). When it comes to religion and ecology, critics point to the pluralistic nature of environment-related religious experience, thereby attempting to move their field beyond its reformist focus on worldviews. Both movements (environmental ethics and religion and ecology) question the connection between cosmology and environmental issues (Jenkins 2009:284). Also, a detailed study of the medieval exegesis of Genesis 1:28 by historians and philosophers of technology revealed that medieval commentators characteristically dealt with questions of God's covenant and human sexuality, bypassing the issue of the technological dominion of nature altogether (Whitney 2005:1736). In fact, there is considerable evidence to show that non-Western and pre-Christian cultures were implicated in environmental damage (Whitney 2005:1736). Drawing from the responses of biblical scholars, eco-theologians, historians and philosophers of technology, it is apparent that the links between religion, technology, environmental decline and economic injustice are hardly as direct or straightforward as White suggests.

Yet, I will also suggest that White's thesis cannot be completely discarded, as it has produced a positive response in the form of practical theological practice and meaningful Christian engagement in human-animal, human-earth, and human-God relationships. These positive outcomes are related to the important role that religion can play in solving the ecological and economic injustice crises. At a time when cultural environmentalism enjoyed little support from religious traditions, White's thesis offered a way of understanding that indifference, whilst at the same time imagining alternatives and exerting pressure for change (Jenkins 2009:295). The pressure for change yielded fruit through religious leadership, ecclesiastical ecumenical bodies and faith communities. Within the arena of practical theological creativity, Christian groups were able to replant trees and sell the carbon offsets in Uganda; teach organic agriculture in Japan; combine mission outreach with rainforest education in Belize; struggle for just water management policies in South Africa and protest illegal forest destruction in Brazil (Jenkins 2009:296). In comparison with the practical initiatives of ecclesiastical communities as mentioned above, how is the Nigerian ecclesiastical community tackling the environmental crisis? 


\section{Nigerian ecclesiastical community and the environmental crisis}

With regard to the alleged importance of religion in any given society, particularly in Africa, as enunciated by Koenig, Mbiti and White, it has become necessary to question how the Christian faith is nurturing and protecting the environment in African societies, with particular reference to Nigeria. To what extent have Christians been able to stem ecological injustice and ultimately socio-economic injustice? This assessment will be based primarily on the engagements of the Christian Association of Nigeria (CAN) and in particular its concern with ecological challenges.

The fact that the church, through her respective structures, was not able to respond to the issues of the dumping of toxic waste by multinational companies in the Koko and Ikom communities, which are Christian communities, may be understandable as it may have needed experts to detect the extent of such toxic disposals. However, other visible activities such as gas flaring and oil spillage which are equally damaging to the environment and hazardous to the lives of church members and which have not been adequately addressed by the church, attest to the church's passive stance in relation to the environmental challenges facing Nigeria (Agbiji 2012:57-58). As is the case with many other issues, the Christian community may have voiced her concern about the environmental perils through the issuing of communiqués (Agbiji 2012:159). Nevertheless, although one may argue that it is not possible for the church to tackle every single issue and that issues such as environmental degradation are best left to the experts and to environmental activists, such excuses may not be sustained in the light of the church's claims to morality, and its claim to be both an agent of change and a community-based organisation (Agbiji 2012:159). Above all, the church as a religious institution has a duty to nurture life and to stand on the side of the oppressed. Given the important role that religion has played in various contexts, as mentioned above, such as in Brazil and South Africa, the role of CAN in addressing environmental injustice leaves much to be desired. I argue that the glaring indifference towards the ecological crisis on the part of CAN could in part be attributed to the absence of a strong theological orientation that could have encouraged an ideological orientation amongst faith communities that would support a sustainable ecological praxis, in response to the on-going ecological issues.

It is on this note that Ime Okopido's presentation, as mentioned in the introduction, marks a new development in terms of the attitude of the Christian faith towards environmental activism. Okopido called on the church to bring her resources to bear on the issues affecting the Nigerian environment. He insisted that both individual Christians and the institutional church must partner with non-governmental organisations (NGOs), communitybased organisations (CBOs) and the Nigerian government to wrestle with the challenges confronting the environment. The views expressed by Okopido, as they relate to environmental concerns, and his call on the church and her leaders to partner with other institutions to address environmental challenges, are of special relevance for this article, as it is the first significant call on the ecumenical church; in fact it is a broad-based religious call to environmental activism. This call to environmental activism can also be seen to contain an attempt to formulate a theological basis for environmental activism on the part of Christians in Nigeria.

Okopido (2010) anchors his theology for the church and the environment and his analysis of the on-going environmental crisis in Genesis, Chapters 1-3, and asserts that the creation of the cosmos was the manifestation of God's wise design. This design proceeded from His mind and culminated in the creation of man and woman, who were made in the image and likeness of God to 'fill the earth' and to 'have dominion over it' as stewards of God. Okopido (2010) postulates that the harmony between God, humankind and the environment (the created world) was disrupted by the sin of Adam and Eve, and the result of this sin was the curse on both the Earth and the human creature, ushering in hard labour and death. He further contends that the implication of God's command to Adam and Eve to 'till the earth' and to 'have dominion over the earth' was not merely a simple conferring of authority, but also a summoning to act responsibly. Accordingly, the church has a responsibility towards creation and she should consider it her duty to exercise that responsibility in public and in collaboration with relevant institutions for the purpose of protecting the earth, water, land, forest and wildlife as gifts of the creator, thereby saving humankind from self-destruction (Okopido 2010).

Meanwhile, it is commendable that in 2010 CAN took the initiative for the first time to raise the awareness of church leaders as regards the task of the church in relation to the environment. Okopido's attempt to develop a theology for the environment is also commendable. It underscores the point that theology is not the exclusive preserve of the experts, but is also open to the endeavours of the faithful as they grapple daily with the issues of life and find light from the word of God. Okopido's theological argument with regard to the environment, in which he used the stewardship motif, is in keeping with the spirit of Douglas John Hall's argument on the concept of stewardship.

Hall (1990:32), in his work, The steward, argues that the steward is one who has been given responsibility for the management and service of something belonging to another, and his office presupposes a particular kind of trust on the part of the owner or master. The steward's responsibility entails accountability and ensuring that the household is both properly fed and protected from thieves. In this regard, stewardship implies that we are responsible for the whole earth, and this responsibility includes the non-human as well as the human world (Hall 1990:148). Although the stewardship motif could inform a Christian's response to the on-going ecological challenges in African societies in general and the Nigerian community in particular, it has its deficiencies. In this article, two deficiencies will be modestly 
analysed: (1) the conferring of so much authority over the rest of creation to humankind; and (2) of equal importance, the cultural relevance of the concept of stewardship (Berry 2012; Gosling [1986] 2010:232).

Drawing inspiration from biblical anthropology, Robert James Berry (2012:177) argues that the Bible story of salvation wrought by a loving God focuses on the importance of relationship. The relationship is a relationship of creator (God) to creature (humans, plants, animals, etc.) and of creatures to one another (all part of the created order), as well as relationships within the Godhead. Therefore the biblical authenticity of the stewardship model of human's care of the earth and the ethical challenges posed by claims regarding the relationship of humans to creation remain problematic (Berry 2012:179). Stewardship remains, like most interpretations of the Genesis concept of 'dominion', an image that depicts the human relationship to creation in an entirely 'vertical' way. It sets humans above the rest of creation, sharply differentiated from it, in God-given charge of it (Bauckham 2011:62). Whilst the stewardship model:

has had an enormous influence for good in giving Christians a framework within which to approach ecological issues with concern and responsibility, it has distinct limitations that consist more in what it does not say than what it does. (Berry 2012:180)

The claim that humans are stewards over creation amounts to hubris, a lack of focus, and the implication is that humans are set over creation, not within it (Berry 2012:179). The notion of human beings as stewards over creation amounts to hubris because it is very dangerous to overestimate one's power to achieve or control things. It constitutes a lack of focus, as such an idea also supposes that humans are co-creators and co-redeemers with God (Berry 2012:179). Such ideas pander to the hubristic modern aspiration of human beings wanting to play the role of gods over the world. Instead of humans seeing themselves as set over creation (and therefore not within it), our creatureliness should be understood as more fundamental than our distinctiveness, as God alone is God (Job 38-41; Berry 2012:179).

Therefore rather than the use of the word 'steward' with reference to the relationship of humans with the rest of creation, a better word might be 'trustee' or 'agent', or even 'creation-carer' (Berry 2012:179). On this premises, the notion of a 'community of creation' of which human beings are a part and within which humans have 'special and distinctive roles' is to be preferred. The creatureliness of humans and other creatures as shown in Job 38-41 relates to Psalm 104, where the picture of an ecological creation is to be found within its theocentric praise of God for his creation. This passage is responded to in Psalm 148 and drawn upon by Jesus in Matthew 6: 25-33 (Berry 2012:180). It is therefore imperative for humans to 're-enter creation' (Bauckham 2011:144) and to live in harmony with the rest of creation as creatures in community of other creatures. Yet a question still remains as to the relevance of the notion of stewardship. Can it supply both an authentic theological and ideological frame of reference for a sustainable ecumenical praxis of environmental and economic justice in African ecclesiastical communities?

\section{Stewardship or what? Towards an African ecumenical theology of the environment}

Addressing the issue of an authentic African Christian theological and ideological frame of reference for a sustainable ecumenical praxis of environmental and economic justice in African ecclesial communities (which include Nigeria) inevitably amounts to engaging with the questions, 'What ought to be going on?' and 'How might the Christian church or faith community respond?' (Osmer 2008:4). This task will also guide the discussion in the following parts of this article. I have previously affirmed the importance of the concept of stewardship with regard to the provision of a Christian frame of reference for engaging in environmental and economic justice issues in any context. However, such frame of reference is basically derived from a North American theological paradigm (Gosling [1986] 2010:323; Hall 1990) and does not find a very strong presence in African communities in comparison with the salience of concepts such as 'community' and 'value for community', which recognise a praxis component to the concept of community. For the purpose of articulating a theology that could provide both an ideological and a praxis-oriented ecclesiastical engagement with issues relating to environmental and economic justice, the concept of community provides a common ground for Africans, for Christians and for the wider society.

Admittedly, the church and the world lack a credible theology and philosophy of nature which takes into consideration the insights and discoveries of both science and theology. This has allegedly contributed to the alienation that exists between God, humanity and nature (Gosling [1986] 2010:322). To a large extent, the problems that are affecting the church and the world in the global arena are also evident in both the Nigerian and African contexts. Any theological endeavour to rediscover the wholeness of creation and to generate appropriate ethical imperatives to act in accordance with this vision must therefore include ecumenical and contextual perspectives (Gosling [1986] 2010:322). This endeavour becomes ecumenical and contextual when it incorporates different theological and philosophical approaches to enrich the discussion. Arguably, it is this approach to environmental concerns on the part of the world ecumenical church (World Council of Churches) that has encouraged the use of middle axioms that have significantly informed an authentic dialogue between theology and science (WCC 1992:11). 'Middle axioms' are 'realisable utopias' which help theology to interact with the concrete data of the world (Gosling [1986] 2010:322). A good example is the phrase 'integrity of creation' which emerged from the sixth Assembly of the World Council of Churches held in Vancouver in 1983.

Very importantly, 'integrity of creation' is the shortened version of the WCC's broader theme of 'justice, peace and the integrity of creation' (WCC 1992:12). Also, in a very 
crucial way, this phrase effectively represents the Church's most significant attempt to provide both a theological and an ideological frame of reference for the engagement of ecclesiastical communities in environmental, socio-political and economic issues in the wider society. Indeed, the vision of WCC in this regard is to provide ethical guidelines for a participatory society which will be both ecologically responsible and economically just, and can effectively struggle with the powers which threaten life and endanger our future (WCC 1992:12). As a middle axiom, the concept of community satisfies ecumenical, contextual and integrity of creation concerns. As churches of the south increasingly recognise the importance of ecological and economic justice issues, they must be enabled to articulate their responses in culturally appropriate ways. In this connection, integrity of creation will necessarily be expressed in a variety of ways, held together within a universal ecumenical framework circumscribed by the Bible, tradition and the social, political, economic, ecological and cultural data of the world (Gosling [1986] 2010:323).

Regarding this crucial endeavour, eminent Ghana theologian John Pobee (cited in Gosling [1986] 2010:323) has urged that it is inadequate to have Africans appropriate the North American and European statement of theology in its entirety without any adjustment and reference to their own context. I find the concept of 'community of creation' which relates to the African understanding of community and 'value for community' (Agbiji 2013: 80-82) particularly relevant to African societies and crucial for the flourishing of creation and the fight against ecological and socio-economic injustice. Whereas the notion of 'community of creation' locates humans as part of creation, the notion of 'value for community' relates to the rational, responsible and lifegiving attitude or conduct of humans towards other humans, the rest of the created order and their creator (God). In the following section, I will show how in a very crucial way the concept of community expressed through the praxis of value for community could contribute towards a more significant engagement of ecclesiastical communities in environmental and economic justice issues.

\section{Value for community as praxis for ecological and socio-economic justice}

African societies have commonalities in a number of areas such as value systems, beliefs and practices. These commonalities largely constitute the African worldview. A cardinal aspect of this view of humans in African society is the concept that humans are beings in community. This situation is no different in Nigeria and it is this understanding of human beings that underpins the saying 'I am, because we are; and since we are, therefore I am' (Mbiti 1999:106). In the African view of the world, the word 'community' refers to more than a mere association of isolated individuals. The term itself suggests bondedness; it refers to the act of sharing and living in communion and communication with each other and with nature (Sindima 2013:7). The implication is that the individualism which is so familiar to Western societies is a foreign notion in African societies. The most abiding principle of the African worldview is expressed by the notion of ubuntu (Mnyaka \& Motlhabi 2005:215; Tsele 2001:213) or kefro. Whilst the word ubuntu/kefro and its varied renditions exists within the Southern African, Central African, East African and Nigeria's Olulumo contexts, the concept underlies the value systems, beliefs and practices of all sub-Saharan African societies. It is also this concept as expressed in various ways in African communities that constitutes the glue that holds these societies together as communities.

In this connection, Kwame Gyekye (1987:5) has argued that ubuntu is a multidimensional concept which represents the core values of African ontologies: respect for any human being, for human dignity and for human life, collective sharedness, obedience, humility, solidarity, caring, hospitality, interdependence and communalism. These are all concepts that foster communalism. Communalism insists that the good of all determines the good of each individual or, put differently, the welfare of each individual depends on the welfare of all (Mnyaka \& Motlhabi 2005:217). Traditional African values (embedded in African traditional religion) sustain a communalistic worldview. Africans do not live for themselves; they live for the community. Such a communalistic approach to life fosters the well-being of the entire community. This includes socio-cultural, economic, moral, political, religious, environmental and ecological aspects.

Although traditional African societies had some harmful cultural practices that were inimical to human life (such as trial by ordeal, or the killing of twin babies), a number of socio-cultural, economic and religious practices were lifegiving. They also reflected a concern for socio-economic and ecological justice. For example, in traditional society, people share food and drink in homes and on social occasions freely. There is hardly the notion of needing an invitation to visit or attend events. Economic exchanges were equitable, as the amassing of wealth was not a major incentive for economic activities. Labour was usually communal, allowing each individual to apply his or her expertise and strength according to that individual's capacity. Streams and rivers that provided water to the community were well protected from pollution and deforestation. Through the practice of shifting cultivation, farm lands were preserved and the use of artificial fertilisers was non-existent. Besides fostering economic justice, these practices made possible good standards of living that led to the flourishing of plant, animal and aquatic life, and the general wellbeing of the environment.

Consequently Mbiti's (1999) position on the value which Africans place on community is unambiguous when he argues that:

[i]n traditional life, the individual does not and cannot exist alone except corporately. He owes his existence to other people, 
including those of past generations and his contemporaries. He is simply part of the whole. The community must, therefore, make, create or produce the individual; for the individual depends on the corporate group. (p. 106)

The traditional African view advocates a meaningful and concrete corporate existence in terms of which each member of the community seeks the wellbeing of his or her kinsmen in both the present and future generations (Narayan 2001:40). Nigerian and indeed African development would do well to build on this heritage which has great value with regard to the transformation of the society. Whatever the ethnic, tribal and religious backgrounds of the different individuals who now constitute Nigerian and other African societies, it is essential that all Africans rise above ethnic, racial and religious considerations and accept the fact of a common destiny that all Africans and indeed all humans share with the rest of the created order. The demarcation between humans and the rest of creation must also be jettisoned.

In addition, humans should respect, celebrate and judiciously use their rich diversity in the interest of building a flourishing world. However, to do this successfully all sentiments, attitudes and practices that are, directly or indirectly, prejudicial to their living as a community must be resisted, rejected and condemned. Africans, and indeed all human beings, would do well to play down what divides them and instead build on what unites them. It should be emphasised at this point that religious, ethnic, racial, social class and political affiliations should no longer count if Nigerians and Africans truly wish to bring about meaningful development in their country and continent. Accordingly, Mbiti's (1999) counsel is invaluable when he states that:

[o]nly in terms of other people [and other creation that make up the community] does the individual become conscious of his own being, his own duties, his privileges and responsibilities towards himself and towards other people [and creatures]. When he suffers, he does not suffer alone but with the corporate group [community]; when he rejoices, he rejoices not alone but with his kinsmen, his neighbors and his relatives whether dead or living. Whatever happens to the individual happens to the whole group [community], and whatever happens to the whole group happens to the individual. (p. 106)

However, when the value for community is parochial and myopic, it may provide impetus for the corrupt and selfish practices which inhibit ecological, socio-economic and political well-being. Accordingly, the critics of traditional society argue that, if African societies are to make good progress, they must, as is the case with developed societies, disentangle themselves from communal ties. However, whilst the emphasis on individualism may have certain temporary benefits, it reinforces negative capitalist ideologies which can lead to both greed and the destruction of community.

The WCC Social Justice and Common Goods policy document has captured the importance of the notion of value for community as vital means of addressing the need for ecological and socio-economic injustice in the community of creation. Reiterating previous positions of the WCC as far back as 1968 at its fourth conference in Uppsala, Sweden, the document states:

Our hope is in him who makes all things new. He judges our structures of thought and action and renders them obsolete. If our false security in the old and our fear of revolutionary change tempt us to defend the status quo or to patch it up with half-hearted measures, we may all perish. The death of the old may cause pain to some, but failure to bring up a new world community may bring death to all. In their faith in the coming Kingdom of God and in their search for his righteousness, Christians are urged to participate in the struggle of millions of people for greater social justice and for world development. (WCC 2011)

The works of scholars such as Larry Rasmussen (1996:322325), Sally McFague (2001:33-67) and Dorothee Sölle and S.A. Cloyes (1984:1-21) are significant in their advocacy for the propagation of community ideals. According to them, the earth should be seen as a community that embraces all life, both human and non-human. In addition, the earth should be viewed as God's body which should be loved, protected and preserved as a sacred responsibility. In a very significant way, this way of viewing the created order places a high value on community. The culture of consumerism, which has its origin in the lifestyles of North America and the developed world, and which Nigerians, Africans and others of the underdeveloped world may be tempted to emulate, should be avoided because of the colossal damage it is inflicting on the planet earth. In other words, Nigerians and Africans of varied tribes, tongues, and creeds should value community by seeing each other as kinsmen, neighbours and members of the same community.

Mary Evelyn Tucker (2008:118-119) has pointed out the role of religion and the Earth Charter in an ethically informed redefinition of a path toward a flourishing human-earth community. At the centre of the human-earth community are the values of reverence, respect, restraint, redistribution, responsibility, and renewal. Such a value-based vision of sustainability as that offered by religion is broad-based and covers past, present and future concerns. These values, which concern the flourishing of all life through ecological harmony, justice, and peace, are in keeping with the concerns of the Earth Charter. These values are also in agreement with the traditional African value for community, epitomised by the concept of ubuntu and the varied words that express this worldview in different African societies.

Whereas the concept of value for community is embedded in traditional African societies, the Christian faith, the Earth Charter and other religions, value for community has to move from an ideological frame of reference into a 'thinking and doing' frame of reference - in other words, praxis. Praxis is the process by which a theory, lesson, or skill is enacted, practiced, or realised (Green 2013:115). In this regard, William L. Partridge (2008:165-166) has argued that the 
practitioner of praxis is engaged in an interaction between theory and activity through which social life is lived, in such a way that the practitioner is compelled to make ethical and political decisions that matter to others and to herself or himself. This is possible precisely because the practitioner of praxis is socially embedded, and to continue being so must constantly adjust both theory and practice.

Meanwhile, the rich in Africa and the rest of the world are still getting richer and the poor are still getting poorer. Ecological challenges are still very evident in climate change, and the huge losses in biodiversity and environmental degradation. Whilst the entire planet Earth as a community is being affected adversely, the poor and non-human species are the worst affected. Assuredly, much still needs to be done to achieve the vision of the United Nations to eradicate extreme poverty by 2015 , as espoused in the Millennium Development Goals (MDGs) (United Nations Economic Commission for Africa [UNECA] 2013:6).

In all, the persistence of socio-economic and ecological injustice indicates that many of the measures being championed by local, international and global political and economic institutions lack a praxis orientation. Value for community as praxis for ecological and socio-economic justice is an ideological and practical engagement which should result in a responsible relationship between human beings and the non-human creation. It is premised on collective sharedness, obedience, humility, solidarity, caring, hospitality, interdependence and communalism. Such an ideological orientation and practical engagement should also be informed by reverence, respect, restraint, redistribution, responsibility, and renewal in the community of creation.

\section{Conclusion}

In this article, I have argued that, whereas the concept of ecological justice lacks a strong theological conceptualisation in the Nigerian ecclesiastical community, Okopido's (2010) ecological prompting of the Nigerian religious leadership in which he used the motif of stewardship to argue for the engagement of religious leadership in ecological activism could be further enhanced by adding the concept of value for community (Agbiji 2012). As a concept, value for community is embedded in African traditional society, in the Christian faith, in other religions and in the Earth Charter. This can give impetus to ecological activism, to a change of lifestyles and to other concrete measures that can lead to the protection of the environment, enhance biodiversity and reduce poverty. Above all, value for community has the potential to tame the arrogance and otherness of human beings which gives rise to the reckless utilisation of the nonhuman creation. Based on their ethical responsibility, the Christian faithful and Christian religious communities and institutions have a responsibility to foster such ideals through lived experience, through advocacy, and through collaboration with individuals and institutions that could work towards such praxis in the earth community.

\section{Acknowledgements Competing interests}

The author declares that he has no financial or personal relationship(s) that may have inappropriately influenced him in writing this article.

\section{References}

Adeyemo, T., 2001, 'Africa's enigma', in D. Belshaw, R. Calderisi \& C. Sugden (eds.) Faith in development, partnership between the World Bank and the churches of Africa, pp. 31-38, Regnum Books International, Oxford.

Agbiji, O.M., 2012, 'Development-oriented church leadership in post-military Nigeria: A sustainable transformational approach', PhD thesis, Stellenbosch University, Stellenbosch.

Agbiji, O.M., 2013, 'Religion, politics and socio-economic development in Africa: refocusing on the critical path to African development', Paper presented at International, Interdisciplinary Conference on 'Politics, probity, poverty and prayer: African spiritualties, economic and socio-political transformation', Legon prayer: African spiritualties, economic and

Amoa, Y., 2001, 'Public and private sector initiatives to combat poverty', in D. Belshaw, R. Calderisi \& C. Sugden (eds.), Faith in development, partnership between the World Bank and the churches of Africa, pp. 145-163, Regnum Books International, Oxford.

Anderson, E.N., 2012, 'Anthropology of religion and environment: A skeletal history to 1970', Journal for the Study of Religion, Nature and Culture 6(1), 9-36. http://dx.doi.org/10.1558/jsrnc.v6i1.9

Bauckham, R., 2011, Living with other creatures, green exegesis and theology, Baylor University Press, Waco.

Berry, R.J., 2012, 'Creation care: Stewardship or what?', Science \& Christian Belief 24(2), 169-185.

Conradie, E.M., 2003, 'How can we help to raise an environmental awareness in the South African context?', Scriptura 82, 122-138. http://dx.doi.org/10.7833/ 82-0-903

Gosling, D. [1986] 2010, 'Towards a credible ecumenical theology of nature', The Ecumenical Review 38(3), 322-331. http://dx.doi.org/10.1111/j.1758-6623.1986. tb01359.x

Green, J., 2013, 'Experience the love: A praxis model of lifelong religious education for justice in the Congregational Church, International Congregational Journal 12(1), justice in $107-126$.

Gyekye, K., 1987, 'An essay on African philosophical thought: The Akan conceptual scheme', Cambridge University Press, Cambridge.

Hall, D.J., 1990, The steward: A Biblical symbol come of age, Eerdmans, Grand Rapids.

Hand, C.M. \& Crowe, J., 2012, 'Examining the impact of religion on environmentalism 1993-2010: Has the religious environmental movement made a difference?', Electronic Green Journal 1(34), 1-15.

Heitink, G., 1999, Practical theology: History, theory, action domains, Eerdmans, Grand Rapids.

Hendriks, J., 2010, 'A change of heart: Missional theology and social development', in I. Swart, H. Rocher, S. Green \& J. Erasmus (eds.), Religion and Social development in post-apartheid South Africa: Perspectives for critical engagement, pp. 275-288, in post-apartheid South SUN Press, Stellenbosch.
SUN

Ityavyar, E.M. \& Thomas, T.T., 2013, 'Environmental pollution in Nigeria: The need for awareness creation for sustainable development', Journal of Research in Forestry, Wildlife and Environment 4(2), 1-14.

Jenkins, W., 2009, 'After Lynn White: Religious ethics and environmental problems', Journal of Religious Ethics 37(2), 283-309. http://dx.doi.org/10.1111/j.14679795.2009.00387.x

Koenig, H.G., 2009, 'Research on religion, spirituality, and mental health: A review', Canadian Journal of Psychiatry 54(5), 283-291.

Mbiti, J.S., 1999, African religion and philosophy, Heinemann, Oxford.

McFague, S., 2001, Life abundant: Rethinking theology and economy for a planet in peril, Fortress Press, Minneapolis.

Mnyaka, M. \& Motlhabi, M., 2005, 'The African concept of ubuntu/botho and its socio-moral significance', Black Theology: An International Journal 3(2), 215-237. http://dx.doi.org/10.1558/blth.3.2.215.65725

Narayan, D., 2001, 'Voices of the poor', in D. Belshaw, R. Calderisi \& C. Sugden (eds.) Faith in development, partnership between the World Bank and the churches of Africa, pp. 39-48, Regnum Books International, Oxford.

Nürnberger, K., 1999, Prosperity, poverty and pollution: Managing the approaching crisis, Zed Books, New York.

Okopido, I.T., 2010, 'Church and environment', Papers presented at the National Conference for Christian leaders, Theme: Church in mission and transformation (unedited), Christian Association of Nigeria (CAN), Abuja.

Osmer, R.R., 2008, Practical theology: An introduction, William B. Eerdmans, Grand Rapids.

Partridge, W.L., 2008, 'Praxis and power', Journal of Community Psychology 36(2), 161-172. http://dx.doi.org/10.1002/jcop.20228 
Proctor, J., 2006, 'Introduction: Theorizing and studying religion', Annals of the Association of American Geographers 96(1), 165-168. http://dx.doi.org/10.1111/ Association of American Geog

Rasmussen, L.L., 1996, Earth community earth ethics, Orbis Books, New York.

Riley, M.T., 2012, 'Rethinking Lynn White: Christianity, creatures, and democracy', Summer Symposium: Religion and environmental stewardship, Yale University, New Haven.

Sachs, J.D., 2005, The end of poverty: How we can make it happen in our time?, Penguin, London.

Sindima, H., 2013, 'Community of life: Ecological theology in African perspective', viewed 11 October 2013, from http://www.religion-online.org/showarticle.asp?title=2327

Sölle, D. \& Cloyes, S.A., 1984, To work and to love: A theology of creation, Fortress Press, Philadelphia.

Tucker, M.E., 2008, 'World religions, the Earth Charter, and sustainability', Worldviews 12, 115-128. http://dx.doi.org/10.1163/156853508X359930

Tsele, M., 2001, 'The role of the Christian faith in development', in D. Belshaw, R. Calderisi \& C. Sugden (eds.), Faith in development, partnership between the World
Bank and the Churches of Africa, pp. 203-218, Regnum Books International, Oxford.
United Nations Economic Commission for Africa (UNECA), 2013, 'Making the most of Africa's commodities: Industrializing for growth, jobs and economic transformation', Economic Report on Africa 2013. Addis Ababa: UNECA, viewed 2 July 2013

World council of Churches (WCC), 1992, Christian faith and the world economy today, WCC Publications, Geneva.

WCC, 2011, Social Justice and Common Goods. Policy paper by the Commission of the Churches on International Affairs, Working group on social justice and common goods, viewed 20 January 2014, from http://www.oikoumene.org/en/resources/ documents/wcc-commissions/international-affairs/economic-justice/socialjustice-and-common-goods-policy-paper

Weaver, J.H., Rock, M.T. \& Kusterer, K., 1997, Achieving broad-based sustainable development: Governance, environment, and growth with equity. Kumarian Press, West Hartford.

Whitney, E., 2005, 'Thesis of Lynn White, (1907-1987)', in B. Taylor (ed.), Encyclopedia of religion and nature, pp. 1735-1737, Continuum, London.

Woodhead, L., 2011, 'Five concepts of religion', International Review of Sociology 21(1), 121-143. http://dx.doi.org/10.1080/03906701.2011.544192 